TITLE:

\title{
Vulnerability and behavioral response to ultraviolet radiation in the components of a foliar mite prey-predator system.
}

\author{
$\operatorname{AUTHOR}(\mathrm{S}):$ \\ Tachi, Fuyuki; Osakabe, Masahiro
}

\section{CITATION:}

Tachi, Fuyuki ... [et al]. Vulnerability and behavioral response to ultraviolet radiation in the components of a foliar mite prey-predator system.. Die Naturwissenschaften 2012, 99(12): 1031-1038

ISSUE DATE:

2012-12

URL:

http://hdl.handle.net/2433/168511

\section{RIGHT:}

The final publication is available at www.springerlink.com; この論文は 出版社版でありません。引用の際には出版社版をご確認ご利用くださ $\omega_{\circ}$; This is not the published version. Please cite only the published version. 
1 Vulnerability and behavioral response to

2 ultraviolet radiation in the components of a

3 foliar mite prey-predator system

4

5

6 Fuyuki Tachi and Masahiro Osakabe

7 Laboratory of Ecological Information, Graduate School of Agriculture, Kyoto

8 University, Kyoto 606-8502, Japan

9 Phone: +81757532267

10 Fax: +81757532267

11 E-mail: mhosaka@kais.kyoto-u.ac.jp (Masahiro Osakabe)

12

13

14 
15 Abstract - Ambient ultraviolet-B (UVB) radiation impacts plant-dwelling arthropods including

16 herbivorous and predatory mites. However, the effects of UVB on prey-predator systems, such as

17 that between the herbivorous spider mite and predatory phytoseiid mite, are poorly understood. A

18 comparative study was conducted to determine the vulnerability and behavioral responses of these

19 mites to ultraviolet (UV) radiation. First, we analyzed dose-response (cumulative irradiance-

20 mortality) curves for the eggs of phytoseiid mites (Neoseiulus californicus, Neoseiulus

21 womersleyi, and Phytoseiulus persimilis) and the spider mite (Tetranychus urticae) to UVB

22 radiation from a UV lamp. This indicated that the phytoseiid mites were more vulnerable than the

23 spider mite, although $P$. persimilis was slightly more tolerant than the other two phytoseiid mites.

24 Second, we compared the avoidance behavior of adult female $N$. californicus and two spider mite

25 species (T. urticae, a lower leaf surface user; Panonychus citri, an upper leaf surface user) in

26 response to solar UV and visible light. N. californicus actively avoided both types of radiation,

27 whereas $P$. citri showed only minimal avoidance behavior. $T$. urticae actively avoided UV as well

28 as $N$. californicus but exhibited a slow response to visible light as well as $P$. citri. Such variation in

29 vulnerability and avoidance behavior accounts for differences in the species adaptations to solar

30 UVB radiation. This may be the primary factor determining habitat use among these mites on host

31 plant leaves, subsequently affecting accessibility by predators and also intraguild competition. 


\section{Introduction}

34 Solar ultraviolet (UV) radiation impacts plant-dwelling arthropods in terrestrial

35 ecosystems (Ballaré et al., 2011). Because of the vulnerability of herbivorous

36 spider mites and predatory phytoseiid mites to solar UV radiation (Ohtsuka and

37 Osakabe 2009; Onzo et al. 2010; Sakai et al. 2012a), these impacts may also occur

38 in foliar mite communities. There is a potential for substantial effects on

39 interspecific interactions among mite species, e.g., competition (Osakabe et al.

40 2006) and predation (Onzo et al. 2010).

41 The herbivorous twospotted spider mite, Tetranychus urticae Koch (Acari:

42 Tetranychidae), is a well-known polyphagous, economically important

43 agricultural pest. Although vulnerable to UV radiation, it can avoid the deleterious

44 effects of direct exposure by remaining on the lower leaf surfaces (Ohtsuka and

45 Osakabe 2009). Avoidance of solar UV radiation is likely to be a major selective

46 force for the preference of T. urticae for lower leaf surfaces (Sakai and Osakabe

47 2010). The component of solar UV radiation that can initiate deleterious effects is

48 ultraviolet-B (UVB: wavelength 280-315 nm), whereas ultraviolet-A (UVA:

49 wavelength 315-400 nm) does not affect the survival and fecundity of T. urticae

50 (Barcelo 1981; Suzuki et al. 2009; Ohtsuka and Osakabe 2009; Sakai and

51 Osakabe 2010).

52 Predatory phytoseiid mites can also increase their survival when exposed to

53 UVB radiation by remaining on the lower leaf surfaces or more effectively inside

54 of domatia (Onzo et al. 2010). Interestingly, a phytoseiid mite Typhlodromalus

55 aripo De Leon, the predominant natural enemy of an important mite pest of

56 cassava, the cassava green mite Mononychellus tanajoa (Bondar), hides within the

57 apex of cassava during the day, and moves to leaves and actively forages during

58 the night (Onzo et al. 2003, 2009). Similar to T. urticae, UVA radiation has no

59 deleterious effects on the survival and fecundity of phytoseiid mites (Onzo et al.

60 2010). This indicates both the vulnerability of phytoseiid mites and T. urticae to

61 ambient UVB radiation and the absence of negative effects following exposure to

62 UVA radiation.

63 Weintraub et al. (2007) observed that a phytoseiid mite Neoseiulus cucumeris

64 (Oudemans) avoided both direct and indirect (reflected) sunlight. They used white

65 paper to reflect sunshine in their study. Because UV of shorter wavelengths is 
only partly reflected, the reflected radiation is mostly composed of visible light and some UVA. Therefore, this implies that phytoseiid mites avoid combinations of UV and visible light radiation or just visible light, but avoidance of UV radiation alone is not clear. In previous experiments using monochromatic UV radiation, adult female $T$. urticae avoided 320 and $340 \mathrm{~nm}$ wavelengths (not affected egg hatchability) but not 280 and $300 \mathrm{~nm}$ wavelengths (no eggs hatched) (Sakai and Osakabe 2010). Tetranychus urticae females might be incapable of recognizing UVB and therefore, use the UVA as a source of information for the avoidance of ambient UVB radiation.

In contrast to the majority of plant-dwelling mites, a substantial proportion of the eggs and adult females of herbivorous Panonychus spider mites are present on the upper leaf surfaces of their host plants, although many juveniles remain on the lower leaf surfaces (Foott 1963; Jones and Parrella 1984). The eggs are a reddish color. A previous experiment using artificial UVB radiation revealed that the eggs of Panonychus citri (McGregor) (Acari: Tetranychidae) are not vulnerable to

81 UVB radiation unlike the whitish eggs of T. urticae (Fukaya et al. unpublished data).

If Panonychus mites reside together with Tetranychus mites on the lower leaf surface, they may experience amensal effects due to the complicated webs produced by herbivorous Tetranychus species (Morimoto et al. 2006; Osakabe et al. 2006). These complex webs function as protection against generalist phytoseiid mite species (McMurtry and Scriven 1964; Osakabe et al. 1987; Osakabe 1988; Sabelis and Bakker 1992). However, the webs can be exploited as an indicator of spider mite presence by type I and II phytoseiid mite species, specialized and selective predators of Tetranychus species, respectively (Hoy and Smilanick 1981; McMurtry and Croft 1997; Furuichi et al. 2005; Yano and Osakabe 2009;

92 Shinmen et al. 2010). To understand the impact of solar UV radiation on the foliar

93 mite community, an understanding of the relative impacts of UVB radiation on

94 competitor, prey, and predator interactions is crucial.

95 We hypothesized that avoidance behavior towards solar radiation would 96 reflect the UVB tolerance of plant-dwelling mites, which can restrict or expand

97 their habitat usage on host plant leaves. We conducted a comparative study to

98 determine the vulnerability and behavioral responses of spider mites and

99 phytoseiid mites to solar UV and visible light radiation. 


\section{Materials and methods}

$101 \quad$ Mites

102 Three species of predatory phytoseiid mite, Neoseiulus californicus (McGregor),

103 Neoseiulus womersleyi Schicha, and Phytoseiulus persimilis Athias-Henriot

104 (Acari: Phytoseiidae), were selected for this study. The mites were provided by

105 the National Institute of Agrobiological Sciences, Japan. N. californicus were

106 originally collected from Japanese pear in Matsukawa, Nagano Prefecture, Japan

$107\left(35^{\circ} 36^{\prime} \mathrm{N}, 137^{\circ} 55^{\prime} \mathrm{E}\right)$ in September 2000 . N. womersleyi were originally collected

108 from roses in Shimoichi, Nara Prefecture, Japan $\left(34^{\circ} 21^{\prime} \mathrm{N}, 135^{\circ} 47^{\prime} \mathrm{E}\right)$ in

109 September 1995. Phytoseiulus persimilis was a laboratory strain that had been

110 established from a population commercially provided by Tomono Agrica Co. Ltd.

111 (Shizuoka, Japan). The phytoseiid mites were reared on T. urticae-infesting

112 kidney bean leaves on water-soaked cotton in Petri dishes (9 $\mathrm{cm}$ diameter).

113 Herbivorous Panonychus citri was originally collected from citrus groves at the

114 National Institute of Fruit Tree Science, Japan $\left(32^{\circ} 36^{\prime} \mathrm{N}, 130^{\circ} 11^{\prime} \mathrm{E}\right)$ on 1 June,

1152007 and reared on kidney bean (Phaseolus vulgaris L.) leaves on water-soaked

116 cotton in Petri dishes $(9 \mathrm{~cm}$ diameter). The T. urticae population (the yellow-

117 green type) had been established from several different localities in Japan and

118 cultured on potted kidney bean plants in the laboratory for at least 6 years. They

119 were also reared on kidney bean leaves on water-soaked cotton in Petri dishes for 120 several generations before use in these experiments.

121 All mites were reared in the laboratory at $25^{\circ} \mathrm{C}$ with a photoperiod of $16 \mathrm{~h}$

122 light:8 h dark, except during the radiation treatments.

\section{Comparative vulnerability to UVB radiation}

124 The vulnerability of eggs to UVB for the three phytoseiid mite species and $T$.

125 urticae was tested as a dose (cumulative irradiance)-response (hatchability)

126 relationship.

127 To test phytoseiid mite eggs, we prepared five Petri dishes ( $9 \mathrm{~cm}$ in diameter).

128 Four kidney bean leaf disks $(2 \times 2 \mathrm{~cm})$ were placed on water-soaked cotton in each

129 of the Petri dishes. Ten adult T. urticae females were transferred from cultures to

130 each leaf disk and allowed to oviposit freely for $24 \mathrm{~h}$. The next day, after the $T$.

131 urticae females were removed, five adult females of one phytoseiid mite species 
132 were introduced to each leaf disk and allowed to lay eggs for $24 \mathrm{~h}$ before being

133 removed. The phytoseiid mite eggs laid on the leaf disks were counted and each

134 Petri dish was assigned to one of five treatments: UVB irradiation $\left(47 \mu \mathrm{W} \mathrm{cm}{ }^{-2}\right)$

135 for $10 \min$ (cumulative irradiance $\left.=0.282 \mathrm{~kJ} \mathrm{~m}^{-2}\right), 20 \min \left(0.564 \mathrm{~kJ} \mathrm{~m}^{-2}\right)$, or 30

$136 \min \left(0.846 \mathrm{~kJ} \mathrm{~m}^{-2}\right)$; UVA irradiation $\left(47 \mu \mathrm{W} \mathrm{cm}^{-2}\right)$ for $30 \min \left(0.846 \mathrm{~kJ} \mathrm{~m}^{-2}\right)$; and

137 a control $\left(0 \mathrm{~kJ} \mathrm{~m}^{-2}\right.$ : kept in a laboratory without exposure to UV irradiation). To

138 test the vulnerability of $T$. urticae to the different radiation treatments, we used

139 eggs within $24 \mathrm{~h}$ of oviposition that were prepared in the same manner as

140 described above, but without the introduction of phytoseiid mites.

141 The lamps used to provide UVB and UVA radiation were the UVL-57 UV

142 lamp and the UVL-53 UV lamp, respectively (UVP, Cambridge, UK).

143 Wavelength spectrums of UVB and UVA radiation peaked at 313 and $369 \mathrm{~nm}$,

144 respectively (Fig. 1). The UVB lamp had tails of emission in both UVA and UVC

145 ranges. The UV lamps were placed approximately $60 \mathrm{~cm}$ above the Petri dishes in

146 an incubator at $25^{\circ} \mathrm{C}$. UV irradiance on leaf disks was adjusted using a UV Light

147 Meter UV-340 (UV Light Meter UV-340; Mother Tool Co. Ltd., Ueda city,

148 Japan), which measured the intensity of UV radiation at a range of wavelengths

149 (290-390 nm; UVA+UVB).

150 After the UV irradiation treatment, the number of hatched and unhatched eggs

151 was counted every day for 4 and 6 days for the phytoseiid mites and T. urticae,

152 respectively. The experiment was repeated three times for each treatment.

153 The results from the four leaf disks in each Petri dish were combined for

154 statistical analyses. Differences in the dose-response relationship for UVB

155 radiation between mite species and the effects of UVA radiation on hatchability

156 were evaluated separately using a Wald test for model objects produced by a

157 generalized linear model (GLM: logit-link, binomial error) including mite species

158 and UVB (UVA) dose as explanatory variables. For the dose-response

159 relationship for UVB radiation, pairwise comparisons among mite species were

160 performed by likelihood ratio tests as a post hoc test, and the resulting

161 probabilities were corrected by a Bonferroni correction method. We used the

162 "glm" modules in the "MASS" package to construct GLMs, "Anova" in the "car"

163 package to perform a Wald test, and "anova" to perform likelihood ratio tests

164 between GLMs, with and without species as explanatory variables, in R software

165 (version 2.14.0; R Development Core Team 2009). 
167 To test for avoidance of solar UV radiation, we prepared three rectangular

168 transparent plastic trays $(7.5 \times 22 \mathrm{~cm})$. A strip of kidney bean leaf strip $(1 \times 6 \mathrm{~cm})$

169 was placed on water-soaked cotton in a dish (Fig. 2a). We placed a strip of wet

170 paper $(0.5 \times 3 \mathrm{~cm}$; Kimwipes; Nippon Paper Crecia Co. $)$ across the center of a

171 leaf disk perpendicular to the longitudinal axis to prevent the movement of mites

172 between the two sides. Then we introduced 10 adult $N$. californicus females to

173 one side of the leaf disk divided by the wet paper. Adult females (10 $q$ ) $)$ of $T$.

174 urticae and $P$. citri were also separately introduced to one side of the leaf disks in

175 the remaining two trays. The three plastic trays were kept in the laboratory for at

176 least $10 \mathrm{~min}$, to allow the mites to settle at one side of the leaf disks.

177 After the strip of wet paper was removed, half of the leaf strip where mites had

178 settled was covered with a UV transparent film (polyethylene film, $30 \mu \mathrm{m}$ thick;

179 Dainichi Sangyo Co., Ltd., Osaka, Japan) and the other half was covered with UV

180 opaque film (HB3 polyester film, $25 \mu \mathrm{m}$ thick; Teijin DuPont Films, Japan)

181 stretched on a plastic frame $(8.0 \times 22.5 \mathrm{~cm}$; Fig. $2 \mathrm{~b})$. The UV opaque film filtered

182 out more than $90 \%$ of UV at wavelengths below $380 \mathrm{~nm}$ (UVC, UVB and most of

183 the UVA) and more than 99\% at wavelengths below $363 \mathrm{~nm}$, while allowing the

184 transmission of $87 \%$ of the wavelengths between 388 and $800 \mathrm{~nm}$ (some UVA

185 and visible light; see Sakai and Osakabe 2010). The UV transparent films allowed

186 the transmission of $84 \%$ of $280-800 \mathrm{~nm}$ (UVB, UVA and visible light) on average 187 (Fig. 2d).

188 Then the tray was exposed to solar radiation for $1 \mathrm{~h}(13: 00-14: 00)$ and the 189 number of individuals on each half of the leaf strips was counted every $10 \mathrm{~min}$ on 190 the roof of a four-story building at Kyoto University in Kyoto City, Japan $\left(35^{\circ} \mathrm{N}\right.$,

$191136^{\circ} \mathrm{E}$ ). The mites were exposed to UV (UVA and UVB) and visible light

192 radiation (UV+, VIS+) on the half of the leaf strip where they had settled. They

193 could avoid solar UV radiation by moving to another half of the leaf strip where

194 they were exposed to visible light radiation (UV-, VIS+).

195 At the same time as the experiment to test UV avoidance described above, we

196 also prepared mites on the leaf strips for an experiment to test for visible light

197 avoidance. The preparation and observation procedures were exactly the same as

198 those used for the UV avoidance experiments. However, half of the leaf strip

199 where mites had settled was covered with the UV opaque film, and the other half 
200 was covered with the UV opaque film and also a visible light opaque film (black

201 polyethylene film, $30 \mu \mathrm{m}$ thick; Dainichi Sangyo Co., Ltd., Osaka, Japan; Fig.

202 2c). The mites were exposed to visible light radiation without UV radiation (UV-,

203 VIS+) on the half of the leaf strip where they had settled. They could avoid visible

204 light radiation by moving to the other half of the leaf strip where both UV and

205 visible light radiation were attenuated (UV-, VIS-; Fig. 2d).

206 The experiments for both UV and visible light avoidance were performed on 7

207 September (air temperature: $29.2^{\circ} \mathrm{C}$ [13:00], weather: clear), 10 September

$208\left(32.6^{\circ} \mathrm{C}\right.$, clear $), 24$ September $\left(23.2^{\circ} \mathrm{C}\right.$, clear $), 29$ September $\left(27.2^{\circ} \mathrm{C}\right.$, clear $)$, and 8

209 October $\left(22.7^{\circ} \mathrm{C}\right.$, clear $), 2011$. The average temperature and weather reported in

210 parentheses above were obtained from the Kyoto Local Meteorological

211 Observatory $\left(35^{\circ} \mathrm{N}, 136^{\circ} \mathrm{E}\right)$ of the Japan Meteorological Agency

212 (http://www.jma.go.jp/jp/amedas/).

213 For the statistical analysis, the data from all dates was combined and analyzed

214 as an experiment without replication. This was because the number of females

215 used in each treatment (10 $q q$ each) was too small to evaluate the difference in

216 ratios. Instead, the series of experiments was performed on clear days within a 1-

217 month period. Individuals which escaped from leaf strips to water-soaked cotton

$218(0-2$ 우 in N. californicus, $0-19 Q$ in T. urticae, and $0-10 q q$ in P. citri in total

219 of all dishes at the each observation time) were excluded from the following data

220 analyses.

221 The differences in mite ratios remaining on the half of leaf strip where they

222 originally settled were evaluated using GLMs for repeated measures of UV and

223 visible light avoidance separately. Then, multiple comparisons were performed

224 using Tukey contrasts. We used "glmer" modules in the "lme4" package to

225 construct GLMs for repeated measures, and "glht" in the "multcomp" package for

226 multiple comparisons, using R software (version 2.14.0; R Development Core

227 Team 2009).

228 To test for an avoidance response, the departure of values from 50\% (the

229 expected random distribution for the "no choice" situation) was tested on the

230 number of individuals on each half after $60 \mathrm{~min}$ for each species by an exact

231 binomial test using "binom.test" modules in the R software. 


\section{Results}

\section{Comparative vulnerability to UVB radiation}

234 Most phytoseiid mites had hatched within 3 days following the UV treatment, and

235 a few eggs exposed to UVB radiation hatched on day 6. Only the $N$. womersleyi

236 eggs exposed to UVA (and some in the control) had hatched by day 6. All of the

237 T. urticae eggs in the control and those exposed to UVA radiation had hatched

238 within 5 days following the treatment, and some eggs exposed to UVB radiation

239 had hatched by day 6 . In the control $\left(0 \mathrm{~kJ} \mathrm{~m}^{-2}\right)$, most eggs of all mite species

240 successfully hatched. The hatchability from all three replications combined in the

241 control condition was $99.4 \%(\mathrm{n}=164)$ in $P$. persimilis, $96.0 \%(\mathrm{n}=124)$ in $N$.

242 californicus, $98.8 \%(\mathrm{n}=169)$ in $N$. womersleyi, and $97.3 \%(\mathrm{n}=224)$ in T. urticae.

243 In the UVB treatments, egg hatchability decreased with increased cumulative

244 UVB irradiance (Fig. 3: Wald test, $\mathrm{df}=1, \chi^{2}=745.7, \mathrm{P}<2.2 \times 10^{-16}$ ). The effect

245 of UVB radiation on egg hatchability varied among the different mite species

246 (Wald test, $\mathrm{df}=3, \chi^{2}=165.38, \mathrm{P}<2.2 \times 10^{-16}$ ). The highest hatchability was

247 found in the spider mite, T. urticae (likelihood ratio tests, corrected $\mathrm{P}<0.001$ ).

248 Phytoseiid mites were more vulnerable to UVB radiation. Among phytoseiid

249 mites, the egg hatchability of $P$. persimilis was higher than that of $N$. californicus

250 (likelihood ratio tests, corrected $\mathrm{P}<0.001$ ) and $N$. womersleyi (likelihood ratio

251 tests, corrected $\mathrm{P}<0.001)$. The dose-response relationship for $N$. californicus and

$252 N$. womersleyi was broadly similar, and no significant was between them

253 (likelihood ratio tests, $\mathrm{P}=0.8333$ ).

254 Exposure to UVA radiation $\left(0.846 \mathrm{~kJ} \mathrm{~m}^{-2}\right)$ had no deleterious effects on the 255 egg hatchability of either phytoseiid mite or spider mite species. The hatchability 256 of eggs exposed to UVA radiation was $98.3 \%$ (for all eggs from the three 257 replications combined, $\mathrm{n}=177)$ in P. persimilis, 98.5\% $(\mathrm{n}=136)$ in $N$.

258 californicus, $100 \%(\mathrm{n}=154)$ in N. womersleyi, and $94.1 \%(\mathrm{n}=270)$ in T. urticae.

259 Although egg hatchability varied between mite species (Wald test, $\mathrm{df}=3, \chi^{2}=$ $26012.1268, P=0.006961)$, it did not differ significantly between the two UVA doses

$261 \quad\left(0\right.$ and $0.846 \mathrm{~kJ} \mathrm{~m}^{-2}$; Wald test, $\mathrm{df}=1, \chi^{2}=0.6183, \mathrm{P}=0.431672$; Data not 262 shown). 


\section{Avoidance of solar UV and visible light radiation}

264 In the experiments to test for the avoidance of solar UV radiation, female $N$.

265 californicus and T. urticae moved rapidly from the UV+ area where they had

266 settled to the UV- area, resulting that more than half females of both species were

267 in the UV- area (exact binomial test, $N$. californicus: $\mathrm{P}=2.465 \times 10^{-10}, T$.

268 urticae: $\mathrm{P}=1.522 \times 10^{-5}$ ). Therefore, the number of females of these mites on the

$269 \mathrm{UV}+$ half of the leaf decreased substantially after $10 \mathrm{~min}$ (Fig. 4a). The response

270 tended to be more sensitive in N. californicus than T. urticae, although no

271 significant difference between species was detected (Tukey method, $\mathrm{P}=0.122$ ). In

272 contrast, the response of $P$. citri was clearly slower than those of $N$. californicus

273 (Tukey method, $\mathrm{P}<0.001$ ) and T. urticae (Tukey method, $\mathrm{P}<0.001$ ). More than

274 half of the P. citri females remained on the UV+ half of the leaf for 60 min (exact

275 binomial test, $\mathrm{P}=0.04703$ ).

276 When the avoidance of visible light radiation was tested, female P. citri and T.

277 urticae displayed similar slow responses (Tukey method, $\mathrm{P}=0.585$ ). They

278 gradually moved and after 60 min were almost evenly distributed between the

279 VIS+ and VIS- regions of the leaf (Fig. 4b; exact binomial test, $P$. citri $: \mathrm{P}=$

280 0.5682, T. urticae: $\mathrm{P}=0.1439)$. Therefore, it is not clear whether the spider mite

281 females actively avoided visible light. In contrast, $N$. californicus responded more

282 rapidly to visible light radiation than $T$. urticae (Tukey method, $\mathrm{P}<0.0001$ ) and

$283 P$. citri (Tukey method, $\mathrm{P}<0.0001$ ). The females remaining in the VIS+ region of

284 the leaf had decreased by approximately $25 \%$ of the number initially settled after

$28520 \mathrm{~min}$, resulting that more than half of $N$. californicus females were in the VIS-

286 area (exact binomial test, $\mathrm{P}=3.846 \times 10^{-5}$ ).

\section{Discussion}

288 Most plant-dwelling mites prefer to remain on lower leaf surfaces (Sudo and

289 Osakabe 2011). Many abiotic factors such as temperature, humidity, wind, rain,

290 and gravity may determine the resource accessibility and exploitation patterns of

291 both herbivorous (Mori 1961; Ferro and Chapman 1979; Boyne and Hain 1983; Li

292 and Margolies 1991; Bounfour and Tanigoshi 2001; Sakai et al. 2012b) and

293 predacious (Shipp et al. 1996; Schausberger 1998; Rowles and O’Dowd 2009)

294 species in foliar mite communities. Of the abiotic factors, Sakai and Osakabe

295 (2010) considered that avoiding UV damage was the primary reason why $T$. 
296 urticae shows a preference for lower leaf surfaces. The mites suffered damage

297 from UVB radiation but not from UVA, and would exploited UVA of a shorter

298 wavelength, e.g., 320 and $340 \mathrm{~nm}$, as a cue to avoid UVB radiation (Sakai and

299 Osakabe 2010).

300 Our previous experiments using a UV lamp revealed that $P$. citri eggs were less

301 vulnerable than $T$. urticae eggs. The hatchability of $P$. citri eggs was $35-55 \%$

302 higher than T. urticae eggs following exposure to UVB radiation (Fukaya et al.

303 unpublished). The dose-response relationships determined in this study revealed

304 that the eggs of phytoseiid mites, especially N. californicus and N. womersleyi,

305 were much more vulnerable to UVB radiation. We also found variation in UVB

306 vulnerability among phytoseiid mite species. The hatchability of $P$. persimilis

307 eggs was intermediate between that of $T$. urticae and other phytoseiid mite species

308 of the genus Neoseulus. Onzo et al. (2010) also reported variation in UVB

309 vulnerability between T. aripo and other phytoseiid mite species. Amblydromalus

310 (= Typhlodromalus) manihoti (Moraes) and Euseius fustis (Pritchard and Baker)

311 avoided UV damage by locating to lower leaf surfaces, whereas the survival and

312 egg production of T. aripo adult females declined when they were irradiated with

313 UVB. T. aripo prevented UV damage by sheltering within domatia at the apices

314 of cassava (Onzo et al. 2010).

315 These differences in UVB vulnerability among mite species might be reflected

316 in the behavioral responses of adult females towards exposure to UV and visible

317 light radiation and affect niche exploitation, because oviposition site selection is

318 likely to depend on the preference of females (Sudo and Osakabe 2011).

319 However, we found that the upper leaf surface user, $P$. citri, did not show a clear

320 response to either UV or visible light irradiation. In contrast, T. urticae, a lower

321 leaf surface user, was sensitive to UV irradiation. Moreover, N. californicus, a

322 plant domatia user (e.g., Palevsky et al. 2008), was sensitive to both UV and

323 visible light irradiation. Generally, plant domatia are exploited by predaceous

324 mites but not by spider mites (Walter 1996). Despite the fact that many phytoseiid

325 mites prefer to lay eggs inside domatia (Walter 1996), P. persimilis is reported to

326 only rarely lay eggs within plant domatia (Palevsky et al. 2008). There is some

327 evidence that leaf hairs and trichomes protect underlying tissues against UVB

328 radiation (Karabourniotis et al. 1993; Skaltsa et al. 1994; Liakoura et al. 1997; 
329 Semerdjieva et al. 2003), implying that eggs laid inside leaf domatia are protected

330 from not only predators and desiccation (Walter 1996) but also UVB damage.

331 The incidence of UV avoidance of T. urticae was equivalent to that of $N$.

332 californicus. The incidence of visible light avoidance of T. urticae was also

333 similar to that of $P$. citri. $T$. urticae does not avoid UV radiation with a

334 wavelength longer than $350 \mathrm{~nm}$ and may not perceive deleterious UVB radiation

335 (Sakai and Osakabe 2010; but see Suzuki et al. 2009). However, positive

336 phototaxis occurs at wavelength of $375 \mathrm{~nm}$ (Naegele et al. 1966). Although

337 McEnroe (1966) described the absence of a response to UV below a wavelength

338 of $360 \mathrm{~nm}$ from the phototaxis viewpoint, our results regarding changes in

339 behavioral response suggest that $T$. urticae can perceive and avoid UV radiation

340 around the 320-340 nm wavelengths (Sakai and Osakabe 2010) in solar radiation.

341 Spider mites have two pairs of eyes (anterior and posterior) and an UV receptor is

342 present in the unshielded posterior eye (McEnroe 1969; McEnroe and Dronka

343 1969).

344 Negative phototaxis of eyeless phytoseiid mites away from visible light has

345 been recorded in several studies (Auger et al. 1999; Weintraub et al. 2007). $N$.

346 californicus negatively and rapidly responded to not only visible light but also

347 solar UV radiation. It has been well documented for this species that vitamin A or

$348 \beta$-carotene (a precursor of vitamin A) are required to induce diapause (Veerman et

349 al. 1983; Veerman 2001). Although photoreceptors and mechanisms concerned

350 with phototactic behavior are not known for $N$. californicus, the response to

351 visible light radiation was gradual compared to the response to UV radiation.

352 Therefore, $N$. californicus might also perceive wavelength differences in the

353 components of the radiation spectrum.

354 Some studies have assumed that the direct effects of solar radiation on the

355 distribution of mites result from heating and a lower humidity in the outer canopy

356 compared to the inner canopy (Villanueva and Childers 2005). In this context, the

357 negative phototaxis of mites might be considered an escape from high

358 temperatures and desiccation during daylight hours (Villanueva and Childers

359 2005) rather than direct UV damage. Air temperatures during the experimental

360 periods for determining avoidance behavior $\left(22.7-32.6^{\circ} \mathrm{C}\right)$ were acceptable for

361 mites. Although solar radiation potentially generates a harsh microenvironment

362 for mites, high temperatures and desiccation may not be the principal effect on 
363 plant-dwelling mites over all seasons. Weintraub et al. (2007) pointed out that the

364 temperature on a leaf surface is substantially cooler than the ambient temperature

365 due to evapotranspiration and that the internal environment of domatia is humid.

366 Many mite species may be able to escape from solar UV damage by moving to

367 the lower leaf surfaces even in the outer canopy. However, highly sensitive

368 species such as some phytoseiid mites might move to the inner canopy or inside

369 domatia during daylight periods. In contrast, some species that can limit UV

370 damage via physical or physiological protection, such as Panonychus mites, can

371 exploit both lower and upper leaf surfaces in the outer canopy, on which they may

372 encounter fewer competitors and natural enemies. Our findings, incorporating

373 with a previous study (Fukaya et al. unpublished), suggest the possibility some

374 herbivorous mites may have evolved tolerance of solar UV radiation as a predator

375 avoidance strategy.

\section{Acknowledgements}

377 We thank Dr. N. Hinomoto who provided phytoseiid mites and Dr. H. Kishimoto who collected $P$.

378 citri. This study was supported by a Grant-in-Aid for Scientific Research from the Ministry of

379 Education, Culture, Sports, Science, and Technology of Japan (18580053).

\section{References}

Auger P, Tixier MS, Kreiter S, Fauvel G (1999) Factors affecting ambulatory dispersal in the predaceous mite Neoseiulus californicus (Acari: Phytoseiidae). Exp Appl Acarol 23: 235250

384 Ballaré CL, Caldwell MM, Flint SD, Robinson SA, Bornman JF (2011) Effects of solar ultraviolet radiation on terrestrial ecosystems. Patterns, mechanisms, and interactions with climate change. Photoch Photobio Sci 10: 226-241

Barcelo JA (1981) Photoeffects of visible and ultraviolet radiation on the two-spotted spider mite, Tetranychus urticae. Photochem Photobiol 33: 703-706

Bounfour M, Tanigoshi LK (2001) Effect of temperature on development and demographic parameters of Tetranychus urticae and Eotetranychus carpini borealis (Acari:

Tetranychidae). Ann Entomol Soc Am 94: 400-404

Boyne JV, Hain FP (1983) Effects of constant temperature, relative humidity, and simulated rainfall on development and survival of the spruce spider mite (Oligonychus ununguis). Can Ent 115: 93-105.

Ferro DN, Chapman RB (1979) Effects of different constant humidities and temperatures on twospotted spider mite egg hatch. Environ Entomol 8: 701-705 
Foott WH (1963) Competition between two species of mites. II. Factors influencing intensity. Can Entomol 95: 45-57

Furuichi H, Yano S, Takafuji A, Osakabe M (2005) Prey preference of the predatory mite Neoseiulus womersleyi Schicha is determined by spider mite webs. J Appl Entomol 129: 336-339

Hoy MA, Smilanick JM (1981) Non-random prey location by the phytoseiid predator Metaseiulus occidentalis: Differential responses to several spider mite species. Enomol Exp Appl 29: $241-253$

Jones VP, Parrella MP (1984) Intratree regression sampling plans for the citrus red mite (Acari: Tetranychidae) on lemons in southern California. J Econ Entomol 77: 810-813

Karabourniotis G, Kyparissis A, Manetas Y (1993) Leaf hairs of Olea europaea protect underlying tissues against ultraviolet-B radiation damage. Environ Exp Bot 33: 341-345

Li J, Margolies DC (1991) Factors affecting location of Banks grass mite, Oligonychus pratensis (Acari: Tetranychidae), on corn leaves. Exp Appl Acarol 12: 27-34

Liakoura V, Stefanou M, Manetas Y, Cholevas C, Karabourniotis G (1997) Trichome density and its UV-B protective potential are affected by shading and leaf position on the canopy. Environ Exp Bot 38: 223-229

McEnroe WD (1966) Color vision in the adult female two-spotted spider mite. Science 154: 782784

McEnroe WD (1969) Eyes of the female two-spotted spider mite, Tetranychus urticae. I. Morphology. Ann Entomol Soc Am 62: 461-466

McEnroe WD and Dronka K (1969) Eyes of the female two-spotted spider mite, Tetranychus urticae. II. Behavioral analysis of the photoreceptors. Ann Entomol Soc Am 62: 466-469

McMurtry JA, Croft BA (1997) Life-styles of phytoseiid mites and their roles in biological control. Annu Rev Entomol 62: 291-321

McMurtry JA, Scriven GT (1964) Studies on the feeding, reproduction, and development of Amblyseius hibisci (Acarina: Phytoseiidae) on various food substances. Ann Entomol Soc Am 57: 649-655

Mori H (1961) Comparative studies of thermal reaction in four species of spider mites (Acarina Tetranychidae). J Fac Agric Hokkaido Univ 51: 574-591

Morimoto K, Furuichi H, Yano S, Osakabe M (2006) Web mediated interspecific competition among spider mites. J Econ Entomol 99: 678-684

Naegele JA, McEnroe WD, Soans AB (1966) Spectral sensitivity and orientation response of the two-spotted spider mite, Tetranychus urticae Koch, from $350 \mathrm{~m} \mu$ to $700 \mathrm{~m} \mu$. J Insect Physiol 12: $1187-1195$

Ohtsuka K, Osakabe Mh (2009) Deleterious effects of UV-B radiation on herbivorous spider mites: they can avoid it by remaining on lower leaf surfaces. Environ Entomol 38: 920-929

Onzo A, Hanna R, Zannou I, Sabelis MW, Yaninek JS (2003) Dynamics of refuge use: Diurnal, vertical migration by predatory and herbivorous mites within cassava plants. Oikos 101:5969 
Onzo A, Hanna R, Sabelis MW (2009) Within-plant migration of the predatory mite

Typhlodromalus aripo from the apex to the leaves of cassava: Response to day-night cycle, prey location and prey density. J Insect Behav 22: 186-195

Onzo A, Sabelis MW, Hanna R (2010) Effects of ultraviolet radiation on predatory mites and the role of refuges in plant structures. Environ Entomol 39: 695-701

Osakabe M (1988) Relationships between food substances and developmental success in Amblyseius sojaensis Ehara (Acarina: Phytoseiidae). Appl Entomol Zool 23:45-51

Osakabe Mh, Inoue K, Ashihara W (1987) Effect of Amblyseius sojaensis Ehara (Acarina: Phytoseiidae) as a predator of Panonychus citri (McGregor) and Tetranychus kanzawai Kishida (Acarina: Tetranychidae). Appl Entomol Zool 22: 594-599

Osakabe Mh, Hongo K, Funayama K, Osumi S (2006) Amensalism via webs causes unidirectional shifts of dominance in spider mite communities. Oecologia 150: 496-505

Palevsky E, Walzer A, Gal S, Schausberger P (2008) Evaluation of dry-adapted strains of the predatory mite Neoseiulus californicus for spider mite control on cucumber, strawberry and pepper. Exp Appl Acarol 45: 15-27

R Development Core Team (2009) R: A Language and Environment for Statistical Computing, Version 2.10.1. R Foundation for Statistical Computing, Vienna, Austria.

Rowles AD, O'Dowd DJ (2009) Leaf domatia and protection of a predatory mite Typhlodromus doreenae Schicha (Acari: Phytoseiidae) from drying humidity. Aust J Entomol 48: 276-281

Sabelis MW, Bakker FM (1992) How predatory mites cope with the web of their tetranychid prey: a functional view on dorsal chaetotaxy in the Phytoseiidae. Exp Appl Acarol 16: 203-225

Sakai Y, Osakabe Mh (2010) Spectrum-specific damage and solar ultraviolet radiation avoidance in the two-spotted spider mite. Photochem Photobiol 86: 925-932

Sakai Y, Sudo M, Osakabe M (2012a) Seasonal changes in the deleterious effects of solar ultraviolet-B radiation on eggs of the twospotted spider mite, Tetranychus urticae (Acari: Tetranychidae). Appl Entomol Zool 47: 67-73

Sakai Y, Sudo M, Osakabe Mh (2012b) A comparison of the effects of gravity and the nutritional advantage of leaf surfaces on fecundity in the two-spotted spider mite (Acari: Tetranychidae). J Acarol Soc Jpn 21: 1-6

Schausberger P (1998) The influence of relative humidity on egg hatch in Euseius finlandicus, Typhlodromus pyri and Kampimodromus aberrans (Acari, Phytoseiidae). J Appl Entomol 122: 497-500

Semerdjieva SI, Phoenix GK, Hares D, Gwynn-Jones D, Callaghan TV, Sheffield E (2003) Surface morphology, leaf and cuticle thickness of four dwarf shrubs from a sub-Arctic heath following long-term exposure to enhanced levels of UV-B. Physiol Plant 117: 289-294

Shinmen T, Yano S, Osakabe Mh (2010) The predatory mite Neoseulus womersleyi (Acari: Phytoseiidae) follows extracts of trails left by the two-spotted spider mite Tetranychus urticae (Acari: Tetranychidae). Exp Appl Acarol 52: 111-118

Shipp JL, Ward KI, Gillespie TJ (1996) Influence of temperature and vapor pressure deficit on the rate of predation by the predatory mite, Amblyseius cucumeris, on Frankliniella occidentalis. Entomol Exp Appl 78: 31-38 
478 Skaltsa H, Verykokidou E, Harvala C, Karabourniotis G, Manetas Y (1994) UV-B protective potential and flavonoid content of leaf hairs of Quercus ilex. Phytochem 37: 987-990

480 Sudo M, Osakabe M (2011) Do plant mites commonly prefer the underside of leaves? Exp Appl Acarol 55: 25-38

Suzuki T, Watanabe M, Takeda M (2009) UV tolerance in the two-spotted spider mite. J Insect Physiol 55: 649-654

484 Veerman A (2001) Photoperiodic time measurement in insects and mites: a critical evaluation of

485 the oscillator-clock hypothesis. J Insect Physiol 47: 1097-1109

486 Veerman A, Overmeer WPJ, van Zon AQ, de Boer JM, de Waard ER, Huisman HO (1983) Vitamin A is essential for photoperiodic induction of diapause in an eyeless mite. Nature

$488 \quad 302: 248-249$

489

Villanueva RT, Childers CC (2005) Diurnal and spatial patterns of Phytoseiidae in the citrus canopy. Exp Appl Acarol 35: 269-280

491 Walter DE (1996) Living on leaves: mites, tomenta, and leaf domatia. Annu Rev Entomol 41:

492 101-114

493 Weintraub PG, Kleitman S, Alchanatis V, Palevsky E (2007) Factors affecting the distribution of a 494 predatory mite on greenhouse sweet pepper. Exp Appl Acarol 42: 23-35

495 Yano S, Osakabe M (2009) Do spider mite-infested plants and spider mite trails attract predatory mites? Ecol Res 24: 1173-1178

497 
Figure legends

501 Fig. 1 Wavelength spectrums of ultraviolet radiation emitted by UVA (broken line) and UVB (solid line) lamps.

Fig. 2 Experimental design for the test to determine avoidance of solar UV and visible light (VIS) radiation by $N$. californicus, $T$. urticae and $P$. citri. (a) Kidney bean leaf strip on water-soaked cotton in a plastic dish, (b) a lid with UV-transparent (UV+, VIS+) and UVopaque film (UV-, VIS+), and (c) a lid with UV-opaque film (UV-, VIS+) on one half of a leaf and a combined UV-opaque and black film (UV-, VIS-) on the other half, (d) wavelength spectrum of transmittance through the different films. UV-transparent film: chain line, UV-opaque film: broken line, UV-opaque and black film: solid line.

Fig. 3 Dose-response relationship following UVB exposure for eggs of T. urticae (open circles), $P$. persimilis (solid triangles), N. californicus (solid circles), and $N$. womersleyi (open triangles). Vertical lines above and below each plot indicate the $95 \%$ confidence interval. Different letters represent the significance in pairwise comparisons by a likelihood ratio test $(\mathrm{P}<0.05)$. The probabilities were corrected by a Bonferroni correction method.

Fig.4 Avoidance of solar UV (a) and visible light (VIS) (b) radiation by P. citri (solid triangle), T. urticae (open circles) and N. californicus (gray diamond). Species with different letters are significantly different from each other according to the Tukey method $(\mathrm{P}<0.001)$. 


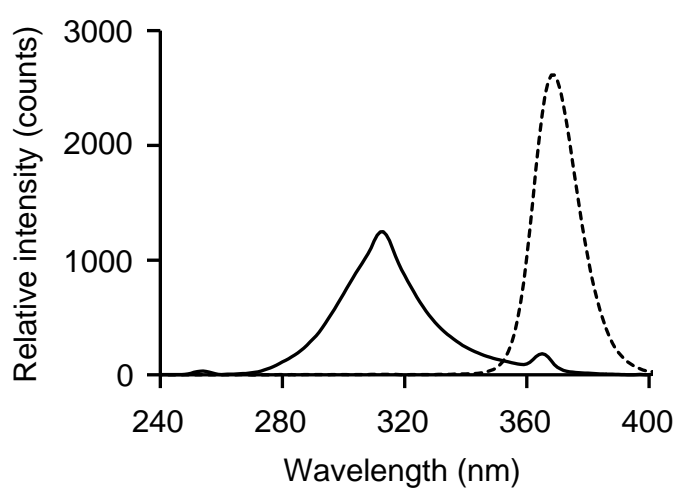

Fig. 1 
(a)

Mites were introduced to one side.

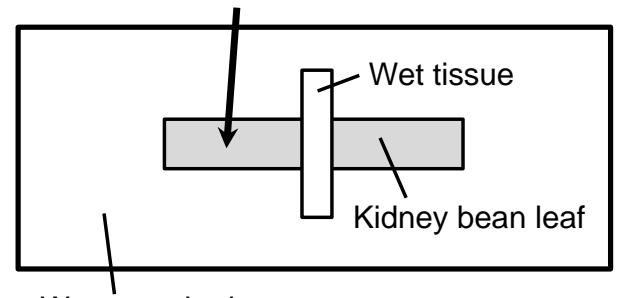

Water-soaked cotton

(b)

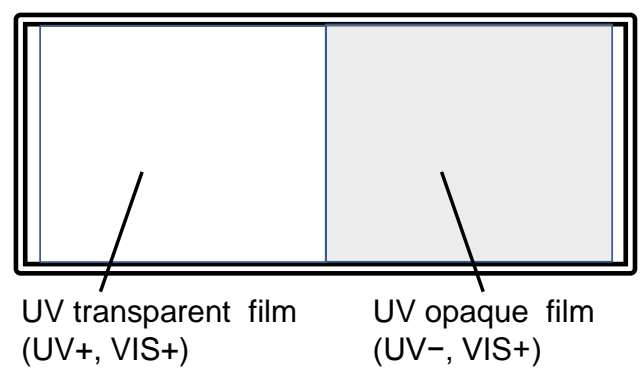

(c)

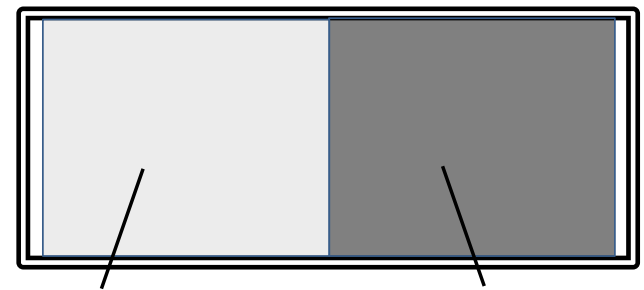

UV opaque film

UV opaque film + (UV-, VIS+)

VIS opaque film (UV-, VIS-)

(d)

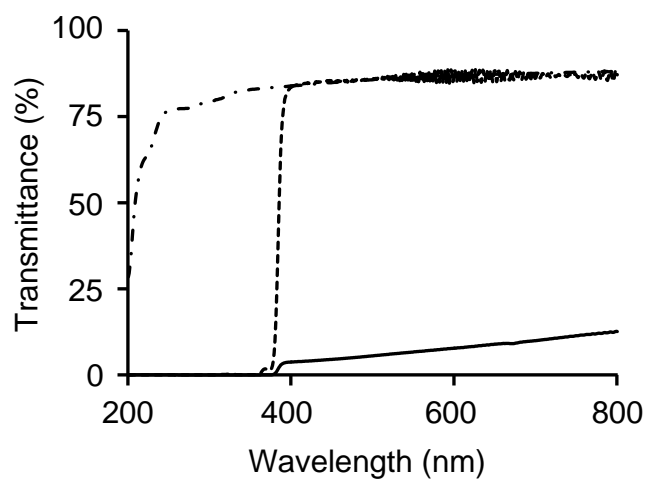

Fig. 2 


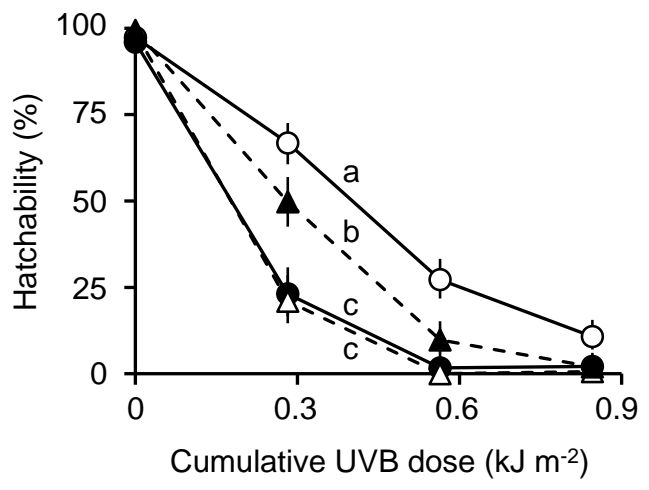

Fig. 3 

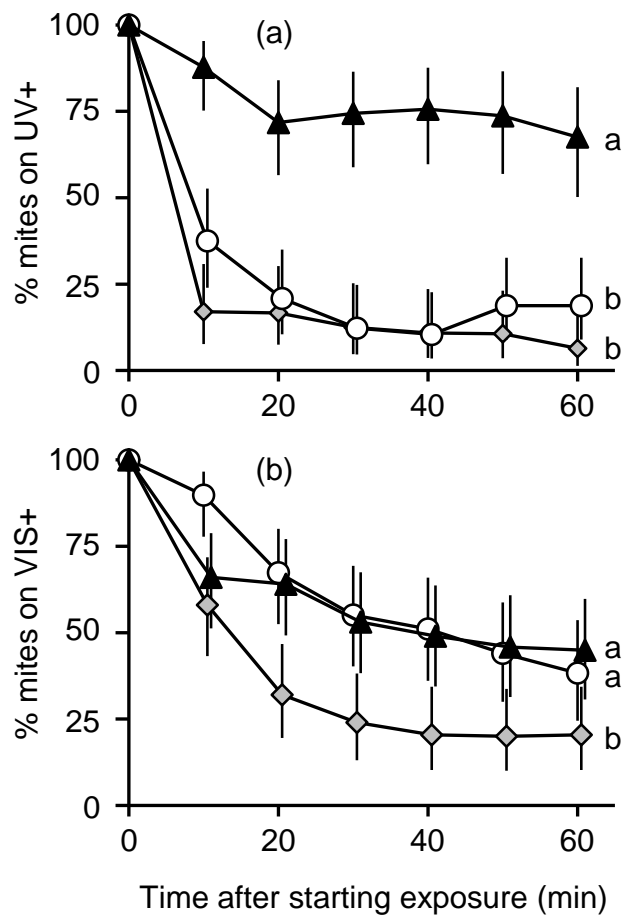

Fig. 4 